\title{
Intraarticular vs Intravenous Tranexamic Acid in Reduction of Blood Loss in Primary Total Knee Replacement
}

\author{
${ }^{1}$ Arunkumar Vijay, ${ }^{2}$ Jambu Nageswaran, ${ }^{3}$ Senthil Loganathan, ${ }^{4}$ Samuel Chittaranjan Bedford
}

\begin{abstract}
Aim: To study the efficacy of topical intraarticular vs intravenous tranexamic acid (TXA) in reducing blood loss following primary total knee replacement (TKR).

Materials and methods: A phase 3 , single center, double blind and randomized controlled study was conducted in the Department of Orthopedics, Sri Ramachandra University, Chennai, Tamil Nadu. A prospective study of 100 patients lasted from July 2013 to July 2015.

Results: Postoperative transfusion rates were zero in both the groups (intraarticular and intravenous). The mean 48-hour drain collected is $285.6 \mathrm{ml}$ in group A (intraarticular), while it is $325.8 \mathrm{ml}$ in group $B$ (intravenous); the mean drop in hemoglobin is $1.7 \mathrm{gm} / \mathrm{dl}$ in group $A$ (intraarticular) while it is $2.4 \mathrm{gm} / \mathrm{dl}$ in group $B$ (intravenous)
\end{abstract}

Conclusion: This study shows that topical intraarticular administration of TXA has better efficacy than intravenous TXA in controlling postoperative blood loss following primary uncomplicated TKR with no significant complications.

Keywords: Intraarticular, Intravenous, Total knee replacement, Tranexamic acid.

How to cite this article: Vijay A, Nageswaran J, Loganathan S, Bedford SC. Intraarticular vs Intravenous Tranexamic Acid in Reduction of Blood Loss in Primary Total Knee Replacement J Postgrad Med Edu Res 2016;50(2):64-68.

Source of support: Though injection Cyklokapron (Tranexamic acid) is a brand of Pfizer company, no grants were obtained from any one.

\section{Conflict of interest: None}

\section{INTRODUCTION}

Total knee arthroplasty (TKA) is a major orthopedic operation that involves significant blood loss because of extensive soft tissue release and bone cuts. The intravenous administration of tranexamic acid (TXA) has shown good results in controlling perioperative blood loss following primary total knee replacement total knee replacement (TKR) TXA, but the complications associated with the intravenous administration of the TXA

\footnotetext{
${ }^{1}$ Senior Resident, ${ }^{2,4}$ Professor, ${ }^{3}$ Assistant Professor

${ }^{1-4}$ Department of Orthopedics, Sri Ramachandra University Chennai, Tamil Nadu, India
}

Corresponding Author: Jambu Nageswaran, Professor Department of Orthopedics, Sri Ramachandra University Chennai, Tamil Nadu, India, Phone: 24768500, e-mail: doctorjambu@gmail.com limit the use in most of the patients. Thus, intraarticular administration of TXA may serve as an effective alternative for intravenous administration. The advantages of intraarticular administration are reduced systemic absorption, maximum concentration at the bleeding site, can be used in patients with renal impairment, cardiovascular diseases, cerebrovascular conditions, ease of administration, and furthermore, the use of tourniquet in TKR results in negligible intraoperative blood loss but notable postoperative blood loss, which is the ideal scenario for using intraarticular hemostatic agents. The aim of this study is to study the efficacy of topical intraarticular vs intravenous TKR in reducing blood loss following primary TKR.

\section{MATERIALS AND METHODS}

A phase 3, single center, double blind and randomized controlled study was conducted in the Department of Orthopedics, Sri Ramachandra University, Chennai, Tamil Nadu, India. This is a prospective study of 100 patients from July 2013 to July 2015. The inclusion criteria for the study were patients undergoing unilateral primary TKR, patients of all age groups, patients of both sexes, both osteoarthritis and rheumatoid arthritis patients and patients who received brand name cyklokapron (tranexamic acid) only were included. The exclusion criteria for the study were patients undergoing bilateral simultaneous TKR, revision TKR, patient needing extensive lateral or posterior release/extensive synovectomy, patients with bleeding diathesis, patients with any contraindication for TXA and patients with sever cardiopulmonary and renal diseases. Totally 100 patients were included in which 50 patients were randomly given intravenous tranexamic and 50 patients were given intraarticular TXA. After obtaining written informed consent from the patients and after obtaining our Institutes Ethical Committee clearance (CCP-MED/13/OCT/09//80), this study was conducted. The collected data were analyzed with Statistical Package for the Social Sciences (SPSS) 16.0 version. To describe about the data descriptive statistics frequency analysis, percentage analysis were used for categorical variables and the mean and standard deviation were used for continuous variables. To find the significant difference between the bivariate samples in paired groups (pre- and 
postoperative) paired sample t-test was used and for independent groups (IA and IV) unpaired sample t-test was used. To find the significance in categorical data chisquare test was used. In all the above statistical tools the probability value 0.05 is considered as significant level. The biochemical schematic formula of TXA is given in Figure 1. The mechanism of action of TXA is given in Figure 2.

\section{TECHNIQUE}

All patients were operated by a single surgeon using standard technique with mid vastus approach with tourniquet inflated $100 \mathrm{~mm} \mathrm{Hg}$ above systolic blood pressure without exsanguinations. Both cruciate retaining and cruciate substituting were done. The wound following the surgery was closed in layers with intraarticular drain and compression dressing. Tourniquet was used in all cases. Patients who underwent primary TKR were randomized into two groups. One group received $2 \mathrm{gm}$ of TXA through the drain (Fig. 3) after skin closure that was clamped for 1 hour following surgery and another group received $10 \mathrm{mg} / \mathrm{kg}$ TXA in $100 \mathrm{ml}$ of normal saline intravenously, one dose before tourniquet release and second dose 3 hours after the surgery. ${ }^{1}$ The postoperative assessments<smiles>NCC1CCC(C(=O)O)CC1</smiles>

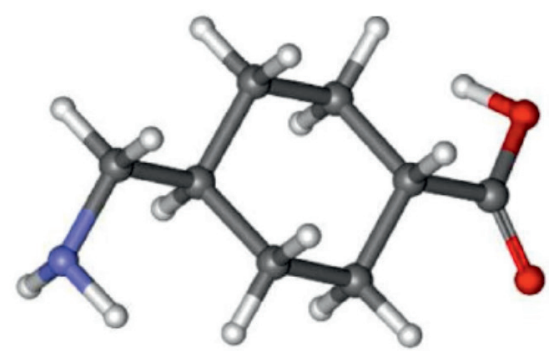

Fig. 1: Tranexamic acid
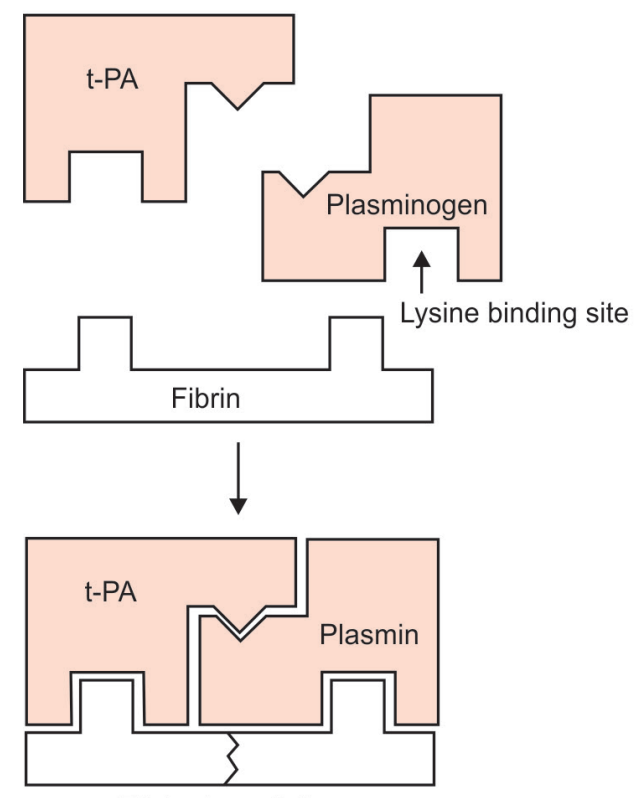

Fibrin degradation products were blood transfusion rates, drop in hemoglobin levels between the two groups, postoperative blood loss measured in drain 48 hours following the surgery and wound healing. The complications, such as deep vein thrombosis, pulmonary embolism, hematoma and hypersensitivity were assessed clinically.

\section{RESULTS}

This study involved 100 patients $(n=100) ; 26$ male patients and 74 female patients who underwent primary TKA. They were divided into two groups 50 in each with 38 female patients in intravenous group, 36 female patients in intraarticular group, 12 male patients in intravenous group and 14 male patients in intraarticular group (Fig. 4) with p >0.05 (Table 1). Group IV represents intravenous hereafter and group IA represents intraarticular in the tables below. A total of 38 patients underwent left primary TKR and 62 patients underwent right TKR (Fig. 5). The difference in hemoglobin is done as independent sample $t$ test (Table 2 ). The mean age group of the patients in the study group were 69 years (Table 3) (Fig. 6) and the mean body mass index (BMI) was 28 (Table 3). Among the 100 patients, the indication for primary TKR was osteoarthritis in 93 patients and rheumatoid arthritis in 7 patients. Group IV stands for intravenous and IA stands for intraarticular. The mean preoperative hemoglobin of the 50 patients $(\mathrm{n}=50)$ in the intravenous group was $10.90 \mathrm{gm} / \mathrm{dl}$ and in the intraarticular group was $10.88 \mathrm{gm} / \mathrm{dl}$. The mean postoperative hemoglobin of the 50 patients $(\mathrm{n}=50)$ in the intravenous group was $9.04 \mathrm{gm} / \mathrm{dl}$ and in
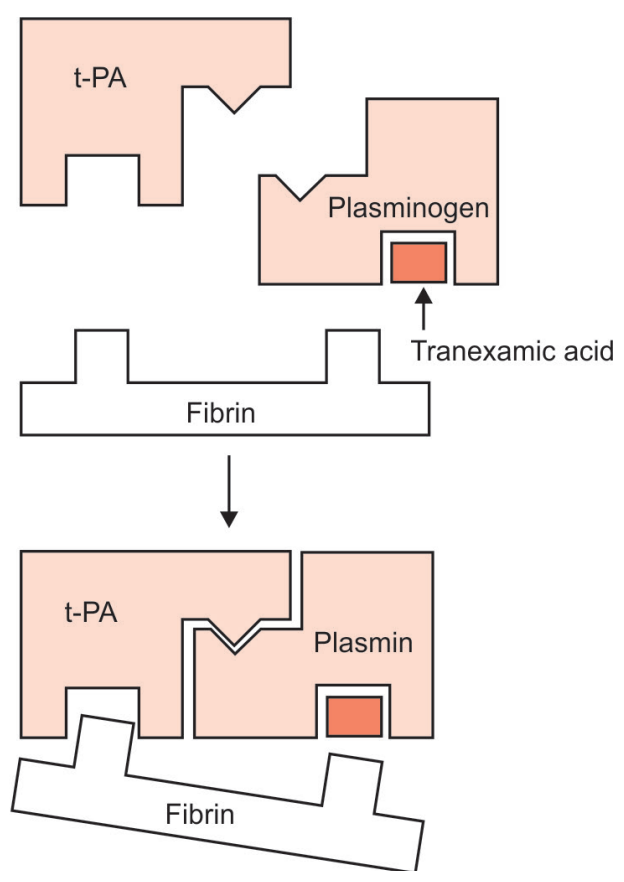

Fig. 2: Mechanism of action 


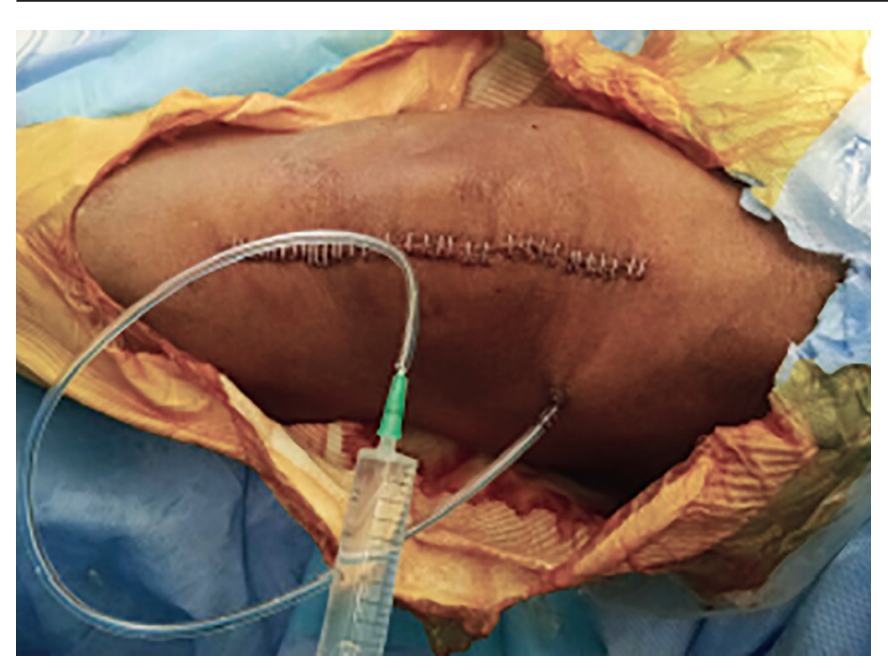

Fig. 3: Intraarticular injection of tranexamic acid through drain

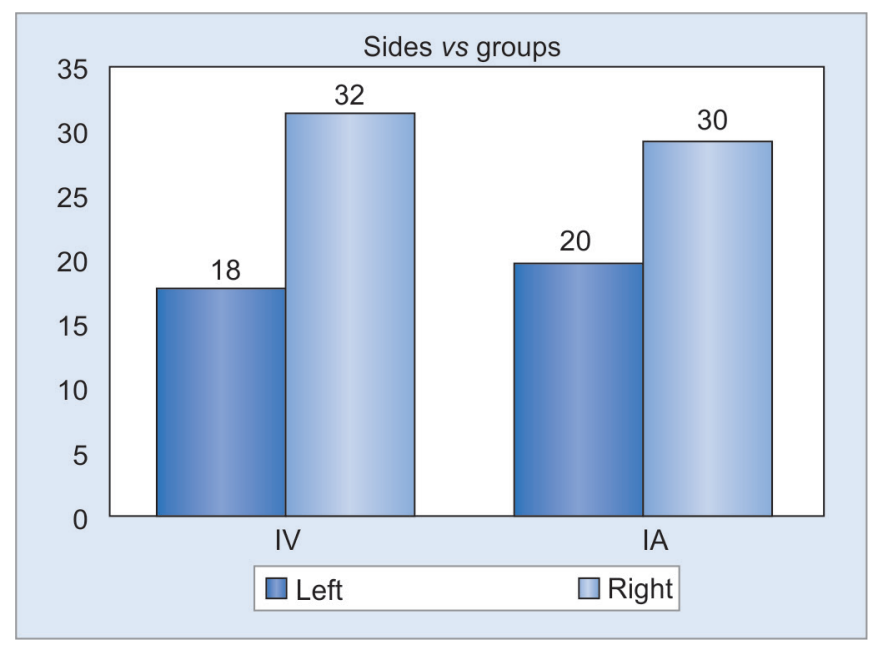

Fig. 5: Side distribution

Table 1: Statistical analysis methods and significanceChi-square test

\begin{tabular}{llllll}
\hline & & & $\begin{array}{l}\text { Asymp. } \\
\text { Sig. }\end{array}$ & $\begin{array}{l}\text { Exact } \\
\text { Sig. }\end{array}$ & $\begin{array}{l}\text { Exact } \\
\text { Sig. }\end{array}$ \\
& Value & Df & (2-sided) & (2-sided) & (1-sided) \\
\hline Pearson chi-square & 0.208 & 1 & 0.648 & - & - \\
Continuity correction & 0.052 & 1 & 0.820 & - & - \\
Likelihood ratio & 0.208 & 1 & 0.648 & - & - \\
Fisher's exact test & - & - & - & 0.820 & 0.410 \\
No. of valid cases & 100 & - & - & - & - \\
\hline
\end{tabular}

the intraarticular group was $9.56 \mathrm{gm} / \mathrm{dl} \mathrm{p}<0.05$ (Table 3). The mean preoperative hematocrit value of the 50 patients in the intravenous group was 32.02 and in the intraarticurlar group was 32.18 . The mean postoperative hematocrit value of the 50 patients in the intravenous group was 27.26 and in the intraarticular group was 28.60 $\mathrm{p}<0.05$ (Table 3). The mean drop in hemoglobin of the 50 patients in the intravenous group was $1.86 \mathrm{gm} / \mathrm{dl}$ and in the intraarticular group was $1.32 \mathrm{gm} / \mathrm{dl} \mathrm{p}<0.05$ (Table 3 and Fig. 7). The mean drop in hematocrit in the intravenous group was 4.76 and in the intraarticular group was $3.58 \mathrm{p}<0.05$ (Table 3). The postoperative blood transfu-

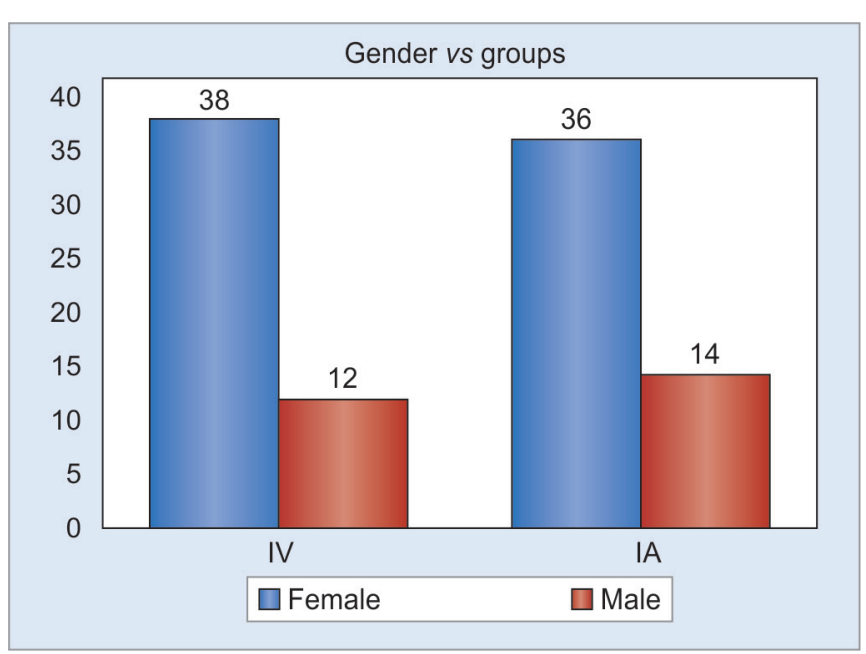

Fig. 4: Sex distribution

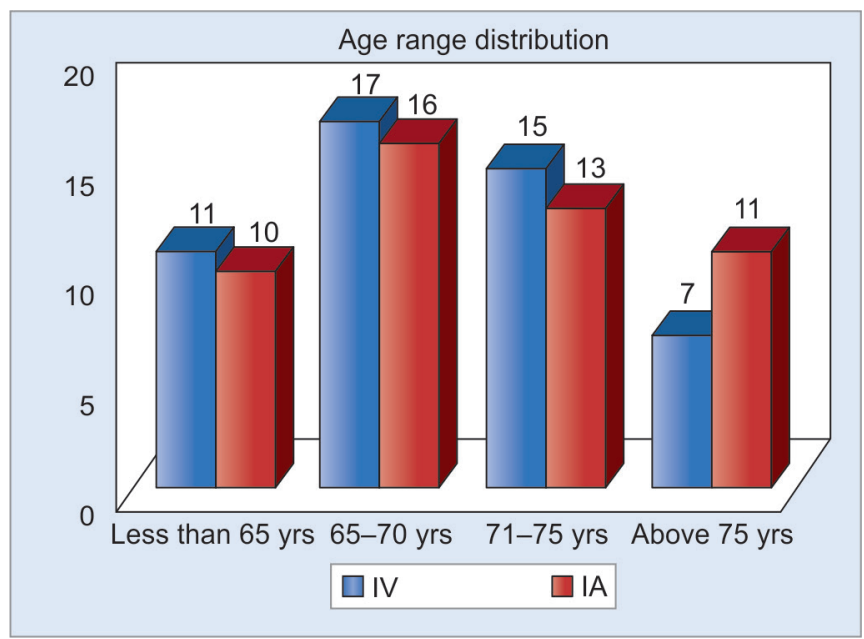

Fig. 6: Age distribution

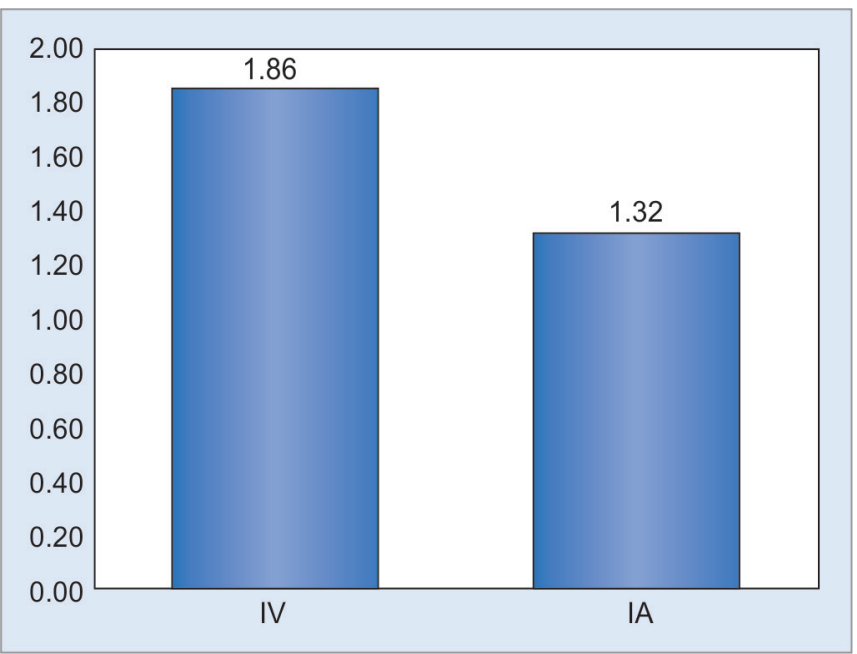

Fig. 7: Hemoglobin difference between pre- and postoperative

sion rates were zero in both the intravenous and the intraarticular group. The mean 48 hours blood loss in drain in the 50 patients of the intravenous group was $320.7 \mathrm{ml}$ and in the intraarticular group was $284.4 \mathrm{ml} \mathrm{p}<0.059$ (Table 3 ). The wound healing was found to be normal in both the groups. One patient in the intraarticular group developed 
Table 2: Independent samples t-test

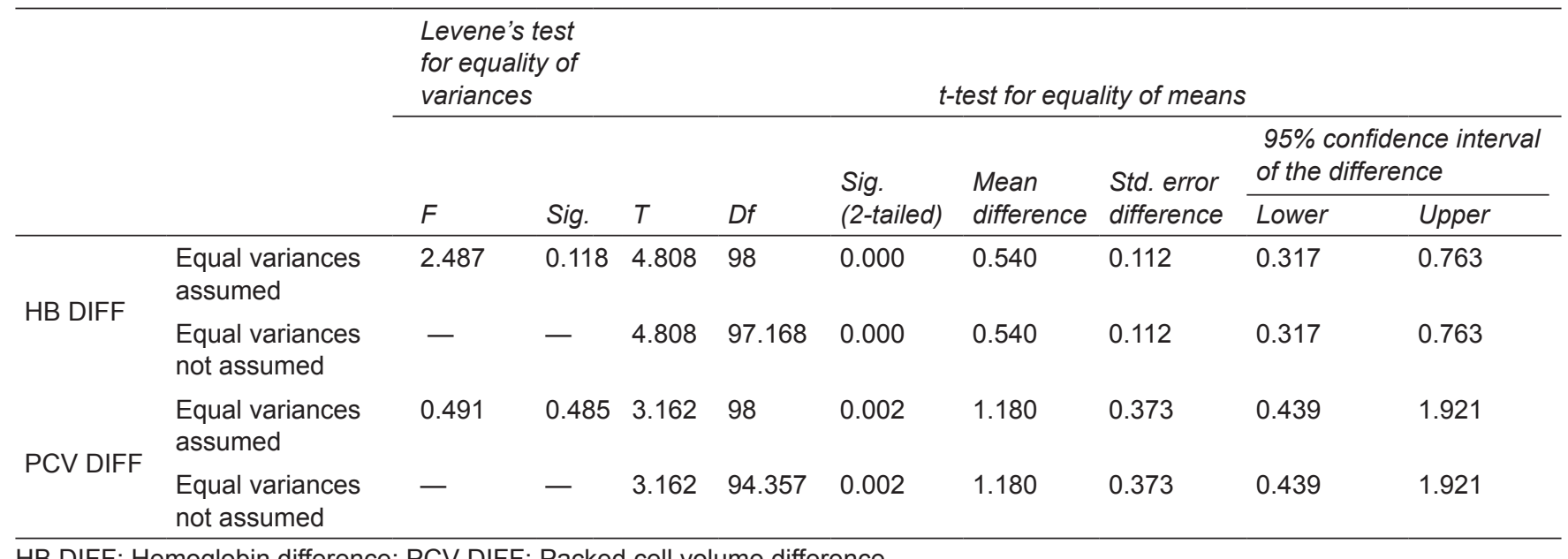

HB DIFF: Hemoglobin difference; PCV DIFF: Packed cell volume difference

Table 3: Mean drop in hemoglobin and mean blood loss in both groups

\begin{tabular}{|c|c|c|c|c|c|c|c|c|c|}
\hline & $\begin{array}{l}\text { Levene's } \\
\text { test for } \\
\text { equality of } \\
\text { variances }\end{array}$ & \multicolumn{8}{|c|}{ t-test for equality of means } \\
\hline & \multirow[b]{2}{*}{$F$} & \multirow[b]{2}{*}{ Sig. } & \multirow[b]{2}{*}{$T$} & \multirow[b]{2}{*}{$D f$} & \multirow{2}{*}{$\begin{array}{l}\text { Sig. } \\
\text { (2-tailed) }\end{array}$} & \multirow{2}{*}{$\begin{array}{l}\text { Mean } \\
\text { difference }\end{array}$} & \multirow{2}{*}{$\begin{array}{l}\text { Std. error } \\
\text { difference }\end{array}$} & \multicolumn{2}{|c|}{$\begin{array}{l}95 \% \text { confidence interval } \\
\text { of the difference }\end{array}$} \\
\hline & & & & & & & & Lower & Upper \\
\hline $\begin{array}{l}\text { Equal variances } \\
\text { assumed }\end{array}$ & 2.073 & 0.153 & -1.026 & 98 & 0.307 & -1.160 & 1.131 & -3.404 & 1.084 \\
\hline $\begin{array}{l}\text { Equal variances } \\
\text { not assumed }\end{array}$ & & & -1.026 & 96.794 & 0.307 & -1.160 & 1.131 & -3.404 & 1.084 \\
\hline $\begin{array}{l}\text { Equal variances } \\
\text { assumed }\end{array}$ & 0.493 & 0.484 & 0.777 & 98 & 0.439 & 0.280 & 0.360 & -0.435 & 0.995 \\
\hline $\begin{array}{l}\text { Equal variances } \\
\text { not assumed }\end{array}$ & & & 0.777 & 89.655 & 0.439 & 0.280 & 0.360 & -0.436 & 0.996 \\
\hline $\begin{array}{l}\text { Equal variances } \\
\text { assumed }\end{array}$ & 0.018 & 0.895 & 0.107 & 98 & 0.915 & 0.020 & 0.187 & -0.351 & 0.391 \\
\hline $\begin{array}{l}\text { Equal variances } \\
\text { not assumed }\end{array}$ & & & 0.107 & 97.862 & 0.915 & 0.020 & 0.187 & -0.351 & 0.391 \\
\hline $\begin{array}{l}\text { Equal variances } \\
\text { assumed }\end{array}$ & 0.622 & 0.432 & -2.804 & 98 & 0.006 & -0.520 & 0.185 & -0.888 & -0.152 \\
\hline $\begin{array}{l}\text { Equal variances } \\
\text { not assumed }\end{array}$ & & & -2.804 & 97.998 & 0.006 & -0.520 & 0.185 & -0.888 & -0.152 \\
\hline $\begin{array}{l}\text { Equal variances } \\
\text { assumed }\end{array}$ & 1.601 & 0.209 & -0.350 & 98 & 0.727 & -0.160 & 0.457 & -1.068 & 0.748 \\
\hline $\begin{array}{l}\text { Equal variances } \\
\text { not assumed }\end{array}$ & & & -0.350 & 96.939 & 0.727 & -0.160 & 0.457 & -1.068 & 0.748 \\
\hline $\begin{array}{l}\text { Equal variances } \\
\text { assumed }\end{array}$ & 0.025 & 0.874 & -2.511 & 98 & 0.014 & -1.340 & 0.534 & -2.399 & -0.281 \\
\hline $\begin{array}{l}\text { Equal variances } \\
\text { not assumed }\end{array}$ & & & -2.511 & 97.860 & 0.014 & -1.340 & 0.534 & -2.399 & -0.281 \\
\hline $\begin{array}{l}\text { Equal variances } \\
\text { assumed }\end{array}$ & 0.777 & 0.380 & 3.242 & 98 & 0.002 & 36.300 & 11.196 & 14.081 & 58.519 \\
\hline $\begin{array}{l}\text { Equal variances } \\
\text { not assumed }\end{array}$ & & & 3.242 & 96.440 & 0.002 & 36.300 & 11.196 & 14.077 & 58.523 \\
\hline
\end{tabular}

HB: Hemoglobin; PCV: Parked cell value

hematoma which was diagnosed clinically on the 4 th postoperative day which needed surgical hematoma evacuation. No other patients had any complications clinically, such as deep vein thrombosis, pulmonary embolism and hypersensitivity.

\section{DISCUSSION}

Tranexamic acid is a synthetic analog of the amino acid lysine. It exerts an antifibrinolytic effect through the reversible blockade of lysine binding sites on plasminogen, thereby reducing the conversion of plasminogen to 
plasmin (fibrinolysin), an enzyme that degrades fibrin clots and fibrinogen. Its biological half life -2 hours, elimination is renal, via glomerular filtration; $90 \%$ of the dose is excreted within 24 hours after administration of $10 \mathrm{mg} / \mathrm{kg}$. A study ${ }^{2}$ showed that the total measured perioperative blood loss in primary uncomplicated TKA is around $1000-1500 \mathrm{ml}$ and postoperative blood loss is estimated around 700-800 ml. Tranexamic acid administration has decreased postoperative blood transfusion. ${ }^{3}$ Various methods of compensating blood loss are allogenic blood transfusion, autologous transfusion, Normovolemic hemodilution and cell salvage. The common side effects of intravenous administration of TXA are nausea, vomiting, diarrhea, dizziness, vision changes, and slurred speech. The absolute contraindication of the drug include severe renal impairment, pregnancy, hypersensitivity, subarachnoids hemorrhage and active intravascular clotting. The complication associated with the drug include venous and arterial thrombosis and thromboembolism, ureteral obstruction and pulmonary embolism, increased incidence of leukemia, hyperplasia of the biliary tract, cholangioma, and adenocarcinoma of the intrahepatic biliary tract. The study ${ }^{4}$ conducted in wed that it reduced absolute risk of blood transfusion by $15.4 \%$ and reduced blood loss by $368 \mathrm{ml}$ compared to placebo. Topically applied TXA was effective in reducing the need for blood transfusion following TKR without important additional adverse effects. A prospective randomized study ${ }^{5}$ involving 89 patients comparing topical administration of $2.0 \mathrm{gm}$ TXA, vs IV group administration of $10 \mathrm{mg} / \mathrm{kg}$. The perioperative change in hemoglobin level, showed a decrease of 3.06 in the IV group and 3.42 in the topical group. Based on this study, to 254 patients underwent unilateral primary cemented TKR received intraarticular TXA topical TXA has similar efficacy to IV TXA for TKA patients with no major complication.

In our study, efficacy of intravenous TXA was compared with the efficacy of intraarticular TXA in controlling blood loss following primary TKA. The study group consisted of patients of statistically similar age, sex and BMI. The postoperative transfusion rates were zero in both the intravenous and intraarticular group. In the study group, the mean drop in hemoglobin in the intravenous group was 1.86 and the mean drop in hemoglobin in the intraarticular group was $1.32(\mathrm{p}=0.0005)$. This shows that the intraarticular administration of TXA has better efficacy in reducing drop in hemoglobin between the pre- and postoperative period than the intravenous group. In the study group, the mean drop in hematocrit in the intravenous group was 4.76 and the mean drop in hematocrit in the intraarticular group was 3.58 ( $\mathrm{p}=$ 0.002). This shows that the intraarticular administration of TXA has better efficacy in reducing drop in hemato- crit between the pre- and postoperative period than the intravenous group. In the study group, the mean 48 hours blood loss in drain in the intravenous group was $320.7 \mathrm{ml}$ and the mean 48 hours blood loss in the intraarticular group was $284.4 \mathrm{ml}(\mathrm{p}=0.002)$. This shows that the intraarticular administration of TXA has better efficacy in reducing blood loss through drain in the postoperative period than the intravenous group. One patient who received intraarticular TXA developed hematoma formation which was surgically evacuated. None of the patient in the intravenous group had hematoma formation. None of the patients developed any other complication, such as DVT, pulmonary embolism and hypersensitivity. Wound healing was normal in all the patients involved in the study group.

\section{CONCLUSION}

Total knee replacement is a major orthopedic surgery with a large amount of blood loss in the perioperative period because of the extensive soft tissue release. Intravenous administration of TXA served as an effective tool in controlling blood loss following primary TKR. But the complication associatedwith the intravenous administration of TXA makes its use limited. This study has shown that the intraarticular administration of the TXA has better efficacy in reducing the drop in hemoglobin and hematocrit and blood loss through drain with negligible complication. This study supports the use of intraarticular TXA in controlling blood loss following primary TKA.

\section{ACKNOWLEDGMENT}

The authors would like to thank and acknowledge all the patients who were subjected to this study.

\section{REFERENCES}

1. Maniar RN, Kumar G, Singhi T, Nayak RM, Maniar PR. Most effective regimen of tranexemic acid in knee arthroplasty: a prospective randomized controlled study in 240 patients. Clin Orthopaed Related Res 2012;470(9):2605-2612.

2. Sehat KR, Newman JH. How much blood is really lost in total knee arthroplasty? The Knee 2000;7(3):151-155.

3. Ho KM, Ismail $\mathrm{H}$. Use of intravenous tranexamic acid to reduce allogenic blood transfusion in total hip and knee arthroplasty a meta analysis. Anaesth Intensive Care 2003;31(5): 529-537.

4. Alshryda S, Mason J, Vaghela M, Sarda P, Nargol A, Maheswaran S, Tulloch C, Anand S, Logishetty R, Stothart B, et al. Hungi topical (intraarticular) tranexamic acid reduces blood loss and transfusion rates following total knee replacement. J Bone Joint Surg 2013;95(21):1961-1968. Available at: http:/ /dx.doi.org/10.2106/JBJS.L.00907

5. Patel JN, Spanyer JM, Smith LS, Huang J, Malkani AL. Comparison of intravenous vs topical tranexamic acid in total knee arthroplasty: a prospective randomized study. Joint Arthroplasty 2014 Aug;29:1528-1531. 